\title{
On the development of a new standard norm in Italian
}

\author{
Massimo Cerruti (University of Turin), Claudia Crocco (Ghent University), Stefania Marzo (KU \\ Leuven)
}

\begin{abstract}
This chapter provides an overview of the main topics concerning the restandardization process of Italian. We will first discuss some general issues related to the Italian sociolinguistic situation, paying special attention to the status of Italo-Romance dialects and their relationship with Italian, the demotization process entailed by the twentieth century massive spread of the standard language, and the connection between neo-standard Italian and regional standards. The focus will then turn to neo-standard Italian: in particular, we will deal with some morphosyntactic features which were excluded from the standard literary norm (codified and established in the sixteenth century) but have survived over time in non-standard varieties. These features finally penetrated the standard usage, progressively giving rise to what is called neo-standard Italian. After a concise review of previous studies on neo-standard Italian, we will situate this variety within the current debate on the development of "new standards" in various European languages. In this respect, special consideration will be given to the notions of "destandardization", "informalization" and "dehomogenization". We conclude by presenting a brief outline of the chapters in this volume.
\end{abstract}

Keywords: neo-standard Italian, restandardization, destandardization, Italo-Romance dialects, regional standards, demotization

\section{Introduction}

In recent years, several theoretical and empirical studies have appeared on the processes of de-/restandardization at work in different European languages, especially relating to dialect/standard convergence phenomena. The growing body of scientific research in this field testifies to the increasing awareness of the theoretical and methodological challenges the field still offers (e.g. Kristiansen and Coupland 2011; Kristiansen and Grondelaers 2013). While most studies have focused on the development of "new standards" in various Germanic languages (cf. Auer, this volume), the present book zooms in on contemporary Italian.

At least since the eighties, it has been claimed that the standard norm of Italian is undergoing substantial changes over the whole Italian peninsula. Italian scholars have interpreted these changes as a process of restandardization, whereby the traditional standard is converging towards spoken, informal and regional varieties. Such a convergence has led to the emergence and diffusion of so-called neo-standard Italian (italiano neo-standard, Berruto 2012 [1987]).

Before giving an overview of the individual contributions, we will first account for some general issues concerning the Italian sociolinguistic situation $(\S 2)$, which is not well-known 
internationally compared to those of other European countries. Subsequently, we will address the notion of neo-standard Italian $(\S 3)$ and briefly sketch a state-of-the-art of research relating to the tendencies and dynamics of restandardization of Italian $(\S 4)$. Finally, we will situate the book chapters in the ongoing debate about de-/restandardization processes $(\S 5)$ and give a succinct outline of each chapter $(\S 6)$.

\section{General issues}

Italian is the national and official language of Italy. Within the national borders, it is spoken alongside more than fifteen Italo-Romance dialects (Piedmontese, Venetian, Sicilian, etc.) and a considerable number of minority languages (Francoprovençal, German, Greek, etc., which have been present in Italy for centuries; "historical linguistic minorities" in Iannàccaro and Dell'Aquila 2011) and "new" immigrant languages (Rumanian, Moroccan Arabic, Chinese varieties, etc., whose speakers have recently immigrated to Italy; "new linguistic minorities" in Chini 2011).

Varieties described as "Italo-Romance dialects", or simply "dialects", are not to be considered as socio-geographical varieties of Italian. Rather, they are to be understood as systems separate from Italian, and could be regarded as non-official regional languages. In fact, the label Italo-Romance dialects applies to the languages developed from Italo-Romance vernaculars, spoken across the country ever since the Middle Ages. Such languages, which in the conventions of Italian research may be referred to as either dialetti italoromanzi or simply dialetti (cf. Grassi, Sobrero and Telmon 1997), are coeval with the Italo-Romance vernacular from which standard Italian developed. It was indeed the literary variety of the fourteenth-century Florentine that was selected as the basis for standard Italian. Hence, Italo-Romance dialects do not derive from the standard language, but predate its spread over the country: they are "primary dialects", in Coseriu's (1980) terminology (see also Regis, this volume). They evolved in parallel with Italian, and may display a noticeable degree of structural distance from it (e.g. Maiden and Parry 1997). On the other hand, contact between Italo-Romance dialects and Italian is intensive and longstanding. In fact, it can be traced back to the sixteenth century, when the Florentine-based standard norm of Italian was codified and established, and all primary dialects became subordinated to the standard language (Serianni and Trifone 1993; Cortelazzo et al. 2002). This long-lasting contact has been resulting both in the "Italianization of the dialects", on the dialect side, and in the "dialectalization (or 'dialectization', Berruto 2005: 83) of Italian”, on the Italian side (see below). 
The situation of linguistic minorities not considered, Italo-Romance dialects were the sole languages for daily use until at least the Unification of Italy (1861). At the time, indeed, Italian was used almost exclusively in writing and formal styles, and only by a small minority of the population (less than 3\% according to De Mauro 1976: 43; about 10\% according to Castellani 1982). Italo-Romance dialects, the low varieties of the repertoire, were hence in a diglossia relationship with Italian, the high variety of the repertoire. Since the political unification, and in particular during the twentieth century, a great number of dialect speakers have shifted to speaking Italian. The use of Italian increasingly spread among the population, both in writing and speaking, as well as in formal and informal situations (e.g. Antonelli 2011).

As a result, the relationship between Italian and Italo-Romance dialects gradually changed into a new one: the high variety of the repertoire also became the language for daily use, alongside the low varieties of the repertoire. In fact, Italian is nowadays regularly used for formal spoken and written purposes, while Italo-Romance dialects, which are functionally subordinate to Italian, are restricted to the family domain and, more generally, to informal situations. Nonetheless, Italian is regularly used in informal situations as well. Therefore both Italian and Italo-Romance dialects are employed for ordinary conversation. This corresponds to the type of linguistic repertoire termed dilalia by Berruto (1989).

Yet, this scenario displays some exceptions. For the historical reasons mentioned above, Florentine and, more generally, the Tuscan dialects show a lower degree of structural distance from Italian (e.g. Calamai, this volume); and the same holds true for the Roman dialect and the dialects of other areas of Central Italy, due to the deep "Tuscanization" which affected them especially in the Renaissance (e.g. Trifone 1992). Consequently, as for Tuscany, it cannot be said for Rome and other areas of Central Italy - unlike the rest of the peninsula - that dialects and standard pertain to separate systems, and the linguistic repertoire reflects closely "the more widespread standard-with-dialects [...] situation" (Ferguson 1959: 336).

At any rate, the twentieth-century massive spread of Italian has progressively led to the decline of Italo-Romance dialects, especially among the highly educated younger generations and in North-Western Italy (cf. Dal Negro and Vietti 2011). In the urban centers of North-Western Italy in particular, Italo-Romance dialects may be considered as endangered languages: they are no longer being learned as mother tongues, and tend to be spoken almost exclusively by the older generations. By way of example, referring to the UNESCO (2003) parameters, Piedmontese (an Italo-Romance dialect spoken in the North-Western Italian region of Piedmont) has recently been assigned a vitality score of 2.4/2.8 (Berruto 2007), situating it halfway between a definitely endangered and a severely endangered language. 
Moreover, Italo-Romance dialects are in the process of replacing some of their original linguistic features with those of Italian, thus becoming more and more similar to their Dachsprache (in the sense of Kloss 1978; Italian is indeed the roof language of all Italo-Romance dialects). In fact, they are generally involved in a process of vertical convergence (more precisely, "advergence"; Mattheier 1996: 34) towards Italian. This replacing of dialect features by those of Italian is commonly referred to as italianizzazione dei dialetti, "Italianization of the dialects" (see Scivoletto 2014 for an up-to-date overview).

On the other hand, the twentieth century massive spread of the standard language has also had effects on the linguistic features of Italian. The standard language underwent a process that may be referred to as "demotization" (cf. Coupland and Kristiansen 2011; Auer and Spiekermann 2011; see also Auer, this volume; the term is inspired by Mattheier's 1997 Demotisierung); that is, it came to be used by the masses of the population, thus becoming "popular" (dèmos 'people' is indeed the etymological root for Demotisierung/demotization). Demotization led to a largescale structural transformation of Italian, which until then had almost only been used in writing and formal styles. In fact, as Italian spread across speakers and situations, it turned into a multifunctional language, and provided itself with linguistic features which can meet the requirement of "immediacy" (see the Koch and Österreicher's 1985 notion of Nähe) for spoken varieties. These linguistic features partly result from the well-known phonological and grammatical processes (such as, for instance, consonant cluster simplification and conjugation regularization) which arise naturally and recur in many sub-standard spoken varieties across languages, wherever they are spoken (Chambers 2004; Trudgill 2011); and are partly due to the transfer of linguistic features from Italo-Romance dialects to Italian, namely, they result from the retention of substratum features. However, the distinction between inherent features of Italian and features induced by contact with Italo-Romance dialects is far from clear-cut, since Italian and ItaloRomance dialects are generally undergoing some similar developments independently of each other (e.g. Cerruti 2011: 16-18).

In any case, after a probable phase of idiosyncratic and/or inconsistent occurrence of features, the progressive stabilization of both nationwide shared and region-specific traits resulted in the emergence of more or less clearly demarcated varieties. More specifically, the relatively stable co-occurrence of certain substratum features, in various areas depending on the different substrata, gave rise to the emergence of different regional varieties of Italian (which presumably traces back to the period between the two World Wars, according to De Mauro 1976: 143-144). In fact, regional varieties of Italian basically resulted from a process of "dialectalization of Italian"; that is, they essentially emerged as a consequence of the retention and subsequent stabilization of features coming from Italo-Romance dialects. Nowadays, common Italian 
speakers regularly speak a regional variety of Italian (alongside, in some cases, an Italo-Romance dialect). Some of them - mostly the older generations - were socialized in an Italo-Romance dialect, others - typically the younger generations - in Italian (however, see Berruto 2003 on the notion of native speaker applied to Italo-Romance). In fact, since the mid twentieth century most dialect speakers have started speaking Italian, the prestige language, to their children, in order to facilitate their social enhancement (De Mauro 1976).

Furthermore, every regional variety of Italian has its social varieties, and each of these social varieties is stylistically stratified. The only exception in this respect is the so-called italiano popolare, i.e. the social variety of Italian mastered by poorly educated speakers, most of whom were previously monolingual dialect speakers. The great majority of speakers of italiano popolare have indeed command of a single variety of Italian, which is used only in formal situations (they always use an Italo-Romance dialect in informal situations) and encompasses little or no stylistic variability (Berruto 2012 [1987]: 127-162).

Standard Italian is codified by grammars and dictionaries and, as far as grammar and vocabulary are concerned, is taught in school. Conversely, the normative standard pronunciation model has always been neglected in teaching. Nowadays it is used almost exclusively by voice professionals (see also Crocco, this volume). Overall, standard Italian does not coincide with any variety actually spoken in Italy. Not even a native speaker of the Florentine variety of Italian can be said to speak standard Italian, since Florentine Italian shows certain regional peculiarities (such as the presence of subject clitics or the spirantization of stops, also known as gorgia) that were excluded from the literary variety codified as standard (the so-called fiorentino emendato, “amended Florentine”, see e.g. Galli de' Paratesi 1984: 57). A fortiori, there are no native speakers of standard Italian.

To return to demotization, the process generally entails influence of the spoken language on the standard variety: the latter, being no longer under the exclusive control of a small intellectual élite, ceases to be conformed only to the written language, and begins to be influenced by the spoken language. That reflects what has happened to Italian as it massively spread over the country. In fact, research has shown (see $\S 4$ ) that many spoken informal features have come to be used and accepted even in formal and educated speech, as well as partly in formal and educated writing, thus gradually leading to the progressive absorption of formerly sub-standard features into standard usage. Hence, the standard variety has come to converge towards spoken informal varieties (see the notion of "downward convergence" in Auer and Hinskens 1996 and in Auer 2005).

Such a process has led to the emergence of a partially renewed standard norm of Italian, which since Berruto (2012 [1987]) is commonly referred to as italiano neo-standard 'neo- 
standard Italian' (although other labels have been used to indicate about the same notion: italiano dell'uso medio, lit. 'Italian of average usage', Sabatini 1985; italiano tendenziale, lit. 'tendential Italian', Mioni 1983; see also ordinary Italian, Lepschy 2002: 66). Neo-standard Italian is constituted in greater part by regionally unmarked linguistic features (see § 3) and in lesser part (and in particular in spoken Italian) by region-specific features (i.e. features of the regional standards).

Different regional standards have indeed emerged (Amenta and Castiglione 2003; Cerruti and Regis 2014; see also the contributions of Regis, Crocco, and Amenta in this volume); each of them mostly consists of retained substratum features that are commonly used and accepted, even in formal situations, by both highly educated and poorly educated speakers (although in specific cases the development of a regional standard does not emerge from dialect/standard convergence; see Vietti, this volume). These regional standards represent different region-specific norms that compete neither with one another nor with the national standard. Neo-standard Italian allows indeed a certain amount of regional differentiation; regional standard features are hence to be considered as "incorporated" into a large core of nationwide shared neo-standard features.

The case of Switzerland Italian may be dealt with separately. Italian is one of the three national and official languages of Switzerland since 1848 (alongside German and French, while Romansh is a national language with a semi-official status). It is spoken in Canton Ticino where Italian is in a dilalia relationship with an Italo-Romance dialect, Ticinese, closely resembling the situation of Italy (e.g. Moretti 2006) - and in the four Italian-speaking valleys of Grisons (Mesolcina, Calanca, Bregaglia, Poschiavo). Besides, it is spoken by Italian immigrants in German-speaking and French-speaking Switzerland, and represents the second or foreign language of a number of non-Italian speaking Swiss (or non-Swiss) citizens. On the one hand, standard Italian in Switzerland may be argued to be influenced by the spoken language, and hence to accept some spoken informal features. On the other hand, standard Italian in Switzerland is influenced by contact with the great languages of the Confederation (German and French), and displays its own political and administrative terminology. In the latter respect, standard Italian in Switzerland slightly differs from standard Italian in Italy. Given the above, it has recently been proposed to consider Italian as a (weakly) pluricentric language (Berruto 2011; Hajek 2012; see also Pandolfi, this volume).

\section{Neo-standard Italian}

As pointed out in the preceding section, contemporary Italian is characterized by a process of "downward convergence" leading to the acceptance of features in earlier times considered as 
non-standard in formal and educated speech and - partly - in writing. Such a process has led to the emergence of a new norm, the so-called neo-standard Italian, which coexists with the traditional standard norm of Italian. Neo-standard mainly consists of features that are "standard by (mere) usage" (Ammon 2003: 2-5), since it regularly occurs in what Ammon (1989, 2003) calls "model texts"; that is, those texts such as literary texts and public speaking, which may serve as a reference point for standard usage and norm codification. In contemporary Italy consistent with a general trend observable in contemporary Europe -, spoken and written texts produced by prominent people in the media prove to exert a greater influence as a model for language usage than those produced by men of letters (see Berruto, this volume). Due to the relevance of newspaper language as a carrier of neo-standard features, it has recently been suggested that neo-standard Italian could even simply be renamed italiano giornalistico ('journalistic Italian'; see Antonelli 2011).

Neo-standard Italian consists of phonological, morpho-syntactic and lexical features. Among them, morpho-syntactic features play a role of primary importance in characterizing this partially renewed standard norm of Italian. These are syntactic constructions such as right and left dislocations, hanging topic, topicalizations, clefting; typical constructions are also the subordination with so-called "che polivalente" (i.e. "multifunctional che" 'that'; see also Cerruti, this volume), and the use of $c$ ' $e$ ('there is') to introduce a presentational clause. Relevant morphosyntactic features are, furthermore, the use of pronominal forms of verbs such as avere ('to have'; see example (4) below), the reflexive use of transitive verbs, and the extended use of the indicative mood at the expense of the subjunctive. Finally, several features concern the expansion of the direct object personal pronouns lui/lei/loro, used as subjects in place of egli/ella/essi ('he/she/they'), and the spreading of the indirect object personal pronoun gli at expenses of le and loro ('to him/to her/to them').

While at first sight these features may appear as recent innovations, in the large majority of cases they are not. In fact, they are already attested in old phases of the Italian linguistic history, as D'Achille (1990) has demonstrated by examining an ample number of Italian texts from the origins to the threshold of the nineteenth century. Moreover, in several cases, comparable traits are widespread in Romance (see Maiden, Smith and Ledgeway 2011-2013). However, despite their antiquity and endogenous Italo-Romance character, these features have long been considered as sub-standard, since their use in the literary language was - often strongly - discouraged by the grammarians during the codification process of Italian.

In the Renaissance, grammars and dictionaries have laid the foundations of the reference norm for literary Italian. In some cases, the grammarian agreed with few exceptions to reject certain usages; such is the case of lui employed as a subject pronoun, a trait which has only 
recently been admitted in normative grammars as acceptable. In other cases, the grammarians did not consistently identify and codify certain features, while also disagreeing with one another concerning the acceptability of a given trait. For instance, left dislocation was admitted by Pietro Bembo but stigmatized by the majority of the other grammarians. In any case, the features that appear today as typical of the neo-standard variety were often rejected or not consistently presented as appropriate to written, especially literary usage. Consequently, during the codification process of standard Italian, this group of traits became marked as non-standard. Yet, while their use was discouraged in writing, these features survived for the whole linguistic history of Italian in spoken and less codified varieties. Indeed, as emphasized by D'Achille (1990), these features have regularly emerged during the centuries in written texts with a typical oral character, such as private correspondence of lowly educated persons, handbooks of bilingual conversation for non-native speakers, etc. This tendency indicates that the features appearing nowadays as characteristic of the neo-standard variety were in fact widespread in spoken Italo-Romance varieties in every period of the Italian linguistic history, although their frequency can vary from one period to another (D'Achille 1990).

To give the reader a glimpse of the persistence of certain features across the centuries, we provide a number of examples from Old and contemporary Italian texts below. The following sentences (1-6) present occurrences of three neo-standard features already attested in Old Italian. They are the pronominal use of avere (averci) $(1,4)$, the use of lui/lei as subject pronouns $(2,5)$ and the (left) dislocation (3,6). Examples from (1) to (3) refer to Tuscan texts preceding 1525, which is the publication year of Bembo's seminal work Prose della volgar lingua. The last three examples, (4-6), by contrast, are extracted from texts recently published in newspapers and magazines with national circulation:

(1) che $c i \quad$ ài $\quad$ tu $\quad$ a $f f$-are ${ }^{1}$
what there have.PRS.2SG you to do-INF
'what are you doing (here)?'
(Ingiurie Lucchesi, Tuscan variety; D'Achille 1990: 271)

$\begin{array}{lllllll}\text { (2) } f u & \text { ved-uto } & \text { apert-issima-mente } & \text { come } & f u & \text { lei } & \text { che } \\ \text { be.PFT.PRS.3SG } & \text { see-PST.PRTC } & \text { open-SUPL-ADV } & \text { how } & \text { be.PFT.3SG } & \text { her } & \text { that } \\ \text { fece } & \text { quello } & \text { busso }^{2} & & & \\ \text { do.PFT.3SG } & \text { that } & \text { noise } & & \end{array}$

\footnotetext{
${ }^{1}$ In contemporary Italian this feature is regionally marked as typical of central and southern Italian (Telmon 1993).

${ }^{2}$ Note that in this example the subject pronoun lei occurs in a cleft sentence.
} 
'it was seen very clearly that it was she that had made that noise'

(Prediche volgari di San Bernardino da Siena, Tuscan variety; D’Achille 1990: 330)

(3) $e$ queste cos-e siate ciert $i$ ch' elli le $\mathrm{fa}$ and these thing-PL be.SBJV.PRS.2PL sure-PL that he them do.PRS.3SG 'and you can be sure that these things, he will do them'

(Criminali pratesi, Tuscan variety; D’Achille 1990: 141)

(4) ma c' avevano il pallino fisso

but there have-IPFV-3PL the bump fixed

'but they had a fixation'

(La Repubblica, June 2000) $)^{3}$

(5) lui ribatt-e che non ce n' è alcun motivo

him reply-PRS.3SG that not there of.it be.PRS.3SG any reason

'he replies that there is no reason for it'

(La Stampa, January 1997) ${ }^{4}$

(6)

$\begin{array}{llllllll}\text { probabilmente } & \text { il } & \text { miracolo } & l & \text { hanno } & \text { fatto } & \text { le banche } \\ \text { probably } & \text { the miracle } & \text { him have.PRS.3PL do.PST.PRTC the banks }\end{array}$

'the miracle, it was probably made by the banks'

(L'Espresso, July 2011)

As the studies on spoken and Old Italian have demonstrated, and as also hinted by the examples above, most neo-standard features are endogenous and already attested in the centuries that preceded the political unification. However, it is worth noting at this point that other neostandard features can indeed be considered as true innovations, unknown to the Italian linguistic system until the twentieth century. At the morpho-syntactic level, this is the case for the multiple focus wh- question, which is a structure borrowed from English (see Berruto, this volume). This

3 This example is taken from an article written by a student: http://ricerca.repubblica.it/repubblica/archivio/repubblica/2000/06/15/la-mia-giornata-tra-dubbimanganelli.html?ref=search (accessed 18.09.2015).

${ }^{4}$ http://archivio.lastampa.it/articolo?id=c2fd5baf82861e3c243ff4b3b40ac40423547e31 (accessed 18.09.2015).

5 This example is taken from a comment article by the Italian columnist Giorgio Bocca: http://espresso.repubblica.it/opinioni/archivio/2011/07/28/news/che-fatica-capire-l-italia-br-1.33688 (accessed 15.09.2015). 
construction occurs nowadays also in "model texts", as illustrated by examples (1) and (2) below, taken from the newspaper La Repubblica:

$\begin{array}{lllll}\text { (7) nessuno } & \text { sa } & \text { chi } & f a & c o s a \\ \text { nobody } & \text { know.PRS.3SG } & \text { who } & \text { do.PRS.3SG } & \text { what }\end{array}$

'nobody knows who does what'

$\left(\right.$ La Repubblica, 04.11.2012) ${ }^{6}$

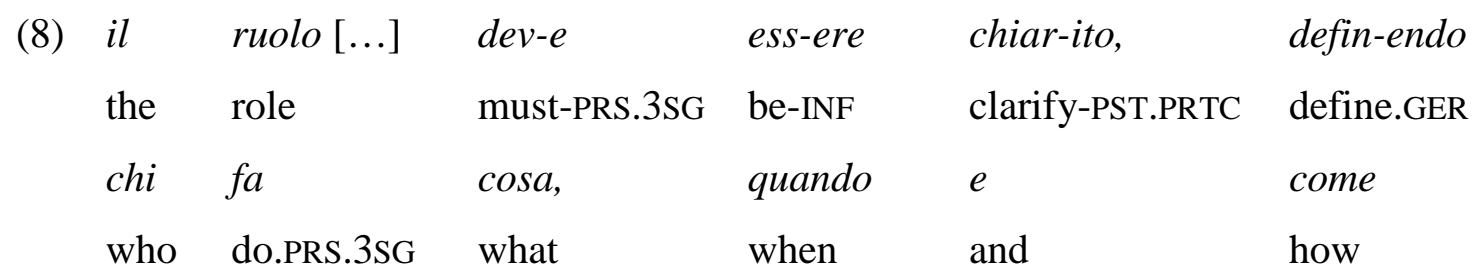

'the role must be clarified, by defining who does what, when and how'

(La Repubblica, 31.08.14) ${ }^{7}$

In conclusion, notwithstanding some exceptions, neo-standard is largely characterized by the admission of a number of ancient and endogenous features into the norm that were formerly marked as oral or non-standard. In contemporary Italian, these features have progressively lost their social and oral markedness acquiring neutrality: whereas the traits themselves are old, their acceptance into the norm is what is truly new in neo-standard.

\section{Research background}

The factors behind the contemporary Italian linguistic scenario have been examined in the last decades by a large amount of studies that tackled the Italian linguistic situation from multiple perspectives. In this section we sketch a brief state-of-the-art of research contributing to identifying and describing the main dynamics related to the restandardization of Italian.

Although the studies on contemporary Italian are largely sociolinguistically-informed, not all of them refer explicitly to theories and methods in the field of sociolinguistic. However, all these studies have contributed in different ways to the understanding of the sociolinguistic

\footnotetext{
6 http://www.repubblica.it/tecnologia/2012/04/11/news/sesso_droga_e_armi_la_faccia_cattiva_del_web-33089682/ (accessed 13.09.15). Note the occurrence in this sentence of another neo-standard feature, i.e. cosa instead of standard che cosa.

${ }^{7}$ http://www.repubblica.it/economia/2014/08/13/news/lettera_ue_bacchetta_1_italia_non_avete_una_strategia_a_risc hio_40_miliardi_di_fondi-93668748/ (accessed 15.09.15). The multiple focus wh-question is between quotation marks since it is a quotation of a UE document. Note also the occurrence in this sentence of another neo-standard feature, i.e. $\cos a$ instead of standard che cosa.
} 
dynamics characterizing the restandardization of Italian. By building an empirical base for the description of the Italian varieties, and exploring the relationship between different varieties, this body of research has in fact sketched an overall picture, which agrees on a number of issues. These include - to mention only the most relevant - the intertwining between neo-standard, regional and spoken varieties, and the role they play in calling into question the primacy of the traditional standard. In addition, the linguistic studies on Italian have touched upon a plurality of themes of sociolinguistic relevance over the years. The focus of this body of research has often changed, following the interests that prevailed within the Italian scientific community at the time. Berruto's annual bibliography in Sociolinguistica (International Yearbook of European Sociolinguistics), together with a number of updated bibliographic overviews provided e.g. by Parry (2010), Berruto (2012) and Cerruti (2013), can give the reader a glimpse of this rich and multifaceted production.

The present-day linguistic scenario finds its roots firstly in the historical processes of formation and dissemination of the standard language, and secondly in the prolonged contact between this variety and the dialects (cf. $\S 1$ ). Unsurprisingly, therefore, Italian sociolinguistics has found a breeding ground in the historical and dialectological tradition of Romance linguistics, which has cast light not only on the formation of the standard variety and the vernaculars (Rohlfs 1966), but also on the dynamics of linguistic contact involving varieties with different geographical and social features, or varieties with different degrees of codification and prestige (Maiden and Parry 1997). As pointed out by Vincent (2006: 13), "[t]he reason is not hard to find. Many, perhaps even most, of the traditional historical questions about the developments from Latin to Romance are - implicitly or explicitly - sociolinguistic". Furthermore, the necessity of taking into account external as well as structural factors in the explanation of linguistic variation and change has often been stressed in the historical studies on Romance (for Italian see Durante 1985).

Since the sixties, with the spread of the Labovian variationist approach and of Weinreich's contact linguistics, the studies on the sociolinguistic (in a broad sense) situation of the peninsula have also increased in number; and one of the most relevant topics in the sociolinguistic-oriented research on Italian has been represented by the relationship between standard language and the dialects. This wide area of studies encompasses the research on the decline of Italo-Romance dialects and their convergence towards the national language, as well as on the linguistic features of regional varieties of Italian and their position in the Italian linguistic repertoire (cf. $\S 1$ ). These issues have been tackled from many perspectives, concerning different fields of linguistics; amongst others: language history (e.g. Bruni 1992), generative linguistics (e.g. Cardinaletti and Munaro 2009), contact linguistics (e.g. Berruto 2005), variationist 
linguistics and sociology of language (e.g. Sobrero and Miglietta 2006; Guerini and Dal Negro 2011), perceptual dialectology (e.g. Cini and Regis 2002), geolinguistics (e.g. Ruffino 1995). In some cases they have been expressly addressed as they relate to the ongoing process of restandardization of Italian (e.g. Cerruti and Regis 2014).

Other studies have drawn attention to the linguistic differences between the everyday Italian language and the standard variety received from the tradition. After the seminal works of Mioni (1983), Sabatini (1985) and Berruto (1987), this emerging variety has been the object of several detailed investigations. Beside a smaller number of works that have examined neostandard features from a theoretical, general linguistic perspective (e.g. Cardinaletti 2004), the majority of the studies have explored a number of - mostly syntactic - neo-standard features focusing on their description as well as on their variational traits: e.g. marked word orders, such as dislocation, topicalizations, and presentational sentences (Berretta 2002; Marzo and Crocco 2015); phrasal verbs (Iacobini and Masini 2009); and relative clauses (Alfonzetti 2002).

In addition to this, a bulk of evidence on the neo-standard variety has been provided by the studies on the italiano giornalistico (cf. $\S 3$; e.g. Bonomi 2002) and, more generally, by the analysis of the language of the mass-media (e.g. Bonomi, Masini and Morgana 2003). It is worth noting here that the journalistic language, which - as mentioned above - is often considered the clearest example of neo-standard (cf. $\S 3$ ), tends to be receptive of morphological (e.g. Bombi 2009; see also Bombi, this volume), syntactic (e.g. Grasso 2007), and lexical innovations, particularly from English (e.g. Dardano, Frenguelli and Perna 2000; see also Asnaghi, this volume).

Conversely, as alluded to in the preceding section (cf. above), most neo-standard features belong to the Italian linguistic system from the earliest days, as is clearly demonstrated by their occurrence in the oldest Italian texts (D'Achille 1990). The oral character of most neo-standard features links this variety to spoken Italian, also explaining why its morpho-syntactic specificities often overlap with those of spoken Italian as such. Since the eighties, spoken Italian has been the research object of a productive strand of studies. Whereas these studies have often focused on phonetic aspects, grammatical structures, or on the pragmatics of speech (e.g. Sornicola 1981; Holtus and Radtke 1985; Voghera 1992), they have also made a fundamental contribution, although indirectly, to the understanding of the dynamics of language changes involving the traditional literary standard. In fact, the research on spoken language has shown come parlano gli italiani ('how Italians speak', De Mauro 1994), pointing out that there was a substantial gap between the traditional norm and the actual linguistic behavior of the Italian speakers. The studies on spoken Italian have also provided a baseline for the analysis of the new varieties emerging in 
Computer Mediated Communication, that are characterized by a peculiar commixture of spoken and written features (e.g. Cerruti, Corino, and Onesti 2011).

Finally, it is worth emphasizing that the research on spoken Italian is, as a matter of fact, inseparable from that on the regional varieties, since oral production in this language is always regionally flavored. Against this background, a relevant contribution to the understanding of the ongoing linguistic trends is provided by studies on regional pronunciation, which in the last decades have examined regional Italian at both the segmental and prosodic level (Canepari 1999; Gili Fivela et al. 2015). Moreover, in recent years an increasing number of studies in sociophonetics have conducted experiments on pronunciation features both from a production and the perception perspective (Celata and Calamai 2014; see also Calamai, this volume), contributing to innovate the strand of research launched in Italy by studies such as Galli de' Paratesi (1984) and Volkart-Rey (1990); see also De Pascale, Marzo, and Speelman (this volume).

Most of the aforementioned issues have been the object of corpus-based investigations, which have been facilitated, in the last decades, by the increasing collection of corpora and other language resources of spoken and written Italian (see Crocco 2015 for an overview). In fact, since the eighties, the collection of corpora has been increasingly considered as a central part of linguistic research on Italian, aimed at creating the preliminary conditions so that large scale empirical studies become more and more customary.

\section{Towards a new standard}

As shown in the previous pages, sociolinguistic research has examined contemporary Italian from several methodological and theoretical viewpoints. Although this diversity of perspectives and approaches could represent a weakness, for the limits it imposes on the comparability of data and results, the studies on the Italian sociolinguistic situation all point in the same direction. They all provide a picture of contemporary Italian as characterized by a bulk of features which are in the process of changing their sociolinguistic value. Like pieces of a mosaic, these studies compose a picture where Italo-Romance dialects are losing ground and, crucially, the traditional standard is losing its position of cornerstone in the repertoire, in favor of a less codified new standard norm that includes a certain degree of regional differentiation and accepts forms and structures coming from spoken informal varieties of Italian. This is probably the main dynamic that we see at work: a process of downward convergence that rests on the expansion of Italian as a spoken language. At the same time, it has been shown that the neostandard norm does not replace the traditional norm, which still enjoys prestige in official domains (Berruto 2012 [1987]). The dissemination of spoken Italian, however, has put pressure 
on the traditional standard pushing it in the direction of regional differentiation (dialect/standard contact) and informal speech, and provoking the introduction of formerly stigmatized features into formal and even written language use.

With this state of affairs, the present volume lines up with the recent strand of studies on current de-/restandardization trends at work in other European languages. Focusing primarily on the dynamics of language change in Germanic languages, European sociolinguists (e.g. Kristiansen and Coupland 2011; Kristiansen and Grondelaers 2013) have put forward two main key concepts to describe standard language change, viz. destandardization and demotization. Demotization, which has been found for instance in Germany and Denmark, occurs when the standard ideology remains unchanged, while the valorization of (informal and socially low) ways of speaking changes (Coupland and Kristiansen 2011: 28). The term indicates that a standard language is used as an Umgangssprache by large groups of the population without necessarily implying a shift in status or ideology. What happens is that the standard language is gradually being used in contexts previously preserved for other varieties (as dialects, or low social varieties). This expansion puts pressure on the standard language which consequently "develops an internal variability which is necessary to serve its manifold functions" (Auer and Spiekermann 2011: 162). In some cases demotization may imply that other varieties take over the title of "best language". As such, it seems to occur in particular when the externally imposed standard language ideology is not largely supported by a population. The emergence of a new norm in this case would rather be a bottom-up process whereby a lower variety is gradually promoted to the accepted norm (cf. usage-based standard ideology, as called by Auer and Spiekermann 2011). At any rate, as stated by Auer and Spiekermann (2011), demotization and destandardization are not mutually exclusive dynamics (see also Auer, this volume). A (de)standardization process can come in exactly when demotization has occurred. Destandardization, as attested for example in Norway, is defined as a process whereby "the established standard language loses its position as the one and only 'best language" (Coupland and Kristiansen 2011: 28). Hence, it loses its normative prestige and starts competing with other varieties. As such, destandardization has been said to occur particularly when the standard norm is less codified and hence more variable (as in Norway).

As shown in the beginning of this chapter $(\S 2)$, in the history of Italian the standard language underwent a process that may be referred to as demotization. Several contributions in this volume (see $\S 6$ ) show indeed how regionally marked and "low" features have started to penetrate the standard language and how the traditional standard is progressively converging downward to these spoken varieties. Such a downward convergence is giving rise to the so-called neo-standard Italian, that coexists with the traditional standard variety. Unlike what typically 
happens with destandardization, there is still no evidence that the traditional standard is losing its official prestige or is replaced by competing varieties. Therefore, this volume focuses on the coexistence between neo-standard Italian and the traditional standard, which is denoted by the term restandardization. This does not mean, however, that destandardization may not have some aspects in common with restandardization: as well as in many cases of destandardization, the restandardization of Italian is increasing the variability of the standard norm and reducing its degree of codification.

Despite the theoretical relevance of the existing framework on standardization dynamics, we are aware that the abovementioned concepts cover highly complex realities and dynamics which cannot always be expressed in one single term. In this regard, Geeraerts and Speelman (2014) have recently noticed that the terminology used for the study of standard languages in Europe does not always cover all linguistic realities. For example, they have argued that it is unclear how destandardization relates to demotization and to which extent there are other underlying processes which are not included by both concepts. For this reason they have advocated for a new terminological apparatus consisting of three dimensions of change, viz. (de)standardization, informalization and (de-)homogenization.

As for Italian, the chapters in this volume all indicate a tendency towards informalization, whereby the standard norm is developing towards more informal, spoken and regional varieties. At the same time, the contributions compose a scenario of dehomogenization, as they show the coexistence between the traditional standard variety and the neo-standard which is less codified and regionally variable (see also Auer, this volume). The overall scope of the volume is to give new empirical evidence for the ongoing process of restandardization of Italian, seeking to give a comprehensive view on the main sociolinguistic dynamics at stake, with different types of data (morphological, syntactical and phonological) from different parts of Italy (from Northern to Central and Southern Italy) and with different approaches (going from production to perception studies) and perspectives.

Most of the papers investigate the process of restandardization from what Kristiansen and Jørgensen (2005) call the more "objective" perspective on standardization dynamics (Kristiansen, Garrett and Coupland 2005). In particular, they scrutinize the "objective factors" of standardization, such as phonological, morphosyntactic and lexical changes. They point to the fact that features of spoken informal and regional varieties are moving upwards, and are currently used in more normative contexts, as in journalistic texts. Two studies in this volume consider restandardization from a "subjective" viewpoint (Kristiansen and Jørgensen 2005), by taking a social-psychological perspective. Whereas the first group of chapters works with production data, 
the last look at perceptions, attitudes and convictions about language use and investigate to what extent these imply a change in standard language ideology.

\section{The structure of the volume}

The volume's chapters are organized in three parts. The first part of the volume looks at the general tendencies and dynamics of restandardization of Italian, with particular reference to syntax and morphology (Chapter 2 and 3). As for pronunciation, attention is paid to the role of restandardization dynamics in the emergence of regional standards (Chapter 4) and to the perception of regional varieties of Italian in comparison to standard Italian (Chapter 5).

In chapter 2, Berruto deals with some aspects of the restandardization process of Italian, as considered both against the backdrop of the present sociolinguistic situation of Italy and in the framework of the ongoing (re-/de-)standardization processes in various European languages, and gives an overall picture of the main morphosyntactic features characterizing neo-standard Italian. Most of these features are not true innovations, as they are consistently found from Old Italian onward, but are changing with regard to social meaning: previously typical of spoken informal varieties, and widely diffused in "low" social varieties, they are becoming commonly used even in formal situations and among educated speakers. Such changes in social meaning affect in particular some marked word orders, the use of certain verb forms and personal pronouns, and the overextension of complementizer che. Cases of true innovations are dealt with as well. This is typically the case with structural patterns borrowed from English, such as the multiple interrogative focus and the ordinal relative superlative.

Chapter 3 focuses on the range of relative constructions as a case in point for the illustration of two different dynamics at work in the process of restandardization of Italian. In this chapter, Cerruti assumes that there exist both varieties lower than standard, namely sub-standard varieties, and varieties higher than standard, such as bureaucratic, refined formal and educated varieties; he terms the latter as "supra-standard" varieties, and argues that both some sub-standard relative constructions and some "supra-standard" relative constructions are in the process of losing their socio-stylistic markedness. Some recent corpus-based studies show indeed that, on the one hand, some sub-standard relative constructions have taken a first step towards that type of norm referred to as standard by mere usage (see $\S 3$ ); and, on the other hand, some "suprastandard" constructions tend to lose their refined formal and highly educated value, in that they are currently appearing in "model texts". These two sociolinguistic dynamics are argued to fit in with the Labovian distinction between changes from below and changes from above. 
In chapter 4, Crocco tackles the problem of pronunciation in contemporary Italian combining diverse perspectives. The chapter describes the main segmental and intonational traits of standard and regional varieties of Italian, while also discussing a number of historical factors that promoted the actual phonetic/phonological fragmentation; finally, the author expounds the role of pronunciation in the ongoing restandardization process of Italian. Looking at the Italian situation, it is striking that standard pronunciation has never spread among educated speakers nor has become native for any socially or geographically defined group of Italians. In contrast, this pronunciation has become an artificial one, mostly used by professionals, such as theatre actors. The regional fragmentation of contemporary spoken Italian results mainly from the prolonged dialect/standard contact, which become pervasive after 1861, and from the - past and present neglecting of pronunciation in school practice. Today, the plurality of pronunciations acts as a force fueling the restandardization process of Italian. While promoting the formation of regiolects and regional informal varieties, the dialect/standard contact has also given an impulse to the formation of diverse pronunciation norms adopted by cultivated speakers from all regions in formal and even official contexts. These are the regional standard pronunciations, which introduce an element of geographical differentiation in the common language.

Whereas the previous chapters depart from production data, chapter 5 (De Pascale, Marzo, and Speelman) looks at speakers' attitudes and analyses to what extent these attitudes reflect a change in standard language ideology. The authors analyze Southern Italian speakers' attitudes towards accent variation in regional and standard Italian and investigate to what extent the language attitudes of these speakers reflect the restandardization process of Italian. In a speaker evaluation experiment, they asked Southern Italian listeners to rate five speech samples. One speech sample was in standard Italian, while the remaining four samples were representative of some regional varieties, viz. the varieties spoken in Milan, Florence, Rome and Naples. Although the authors leave the question aside whether there is an ongoing reorganization of standard language ideology affecting evaluations of spoken Italian, the data in this study clearly point towards a dynamism in language ideology and in particular towards a change in valorization of regional accents. Linear trends across age groups show a decreasing dissatisfaction with the Milanese variety for younger generations, clearing the way for acceptance as "best language". They also reveal a decreasing appreciation of speakers' most closest regional variety, viz. Neapolitan Italian, showing an aggravation of the already widespread stigma on this variety.

The second part of the volume turns to the so-called regional standards of Italian, viz. standard varieties of Italian resulting from the process whereby regional features are moving up to function in domains that were previously associated with standard varieties. All the chapters in 
this second part address the retention of substratum features and their acceptance as part of a regional standard, focusing on different geographical areas (Piedmont, Chapter 6; South Tyrol, Chapter 7; Tuscany, Chapter 8; Sicily, Chapter 9).

In the first chapter of the second part (chapter 6), Regis examines the main sociolinguistic dynamics underlying the formation of regional standards, and focuses on three features of what is called "standard Piedmontese Italian" (i.e. the standard variety of Italian spoken and written in Piedmont). In particular, Regis analyses the use of the definite articles $l o$ and gli instead of $i l$ and $i$ before suocero ('father-in-law'), the occurrence of the focus particle solo più (lit. 'only more') and the omission of the preverbal negation in constructions such as importa niente ("it does not matter'). Regis discusses how these three features are used in "model texts" (viz. texts written by journalists and authors) and have thus acquired a certain degree of standardness. The analysis is provided in terms of simplification/complexification and, following Van Coetsem's language contact model, source/recipient language agentivity.

In chapter 7, Vietti deals with the variety of Italian spoken in Bolzano, which may be considered as an exceptional case in the Italian sociolinguistic situation. Such variety does not emerge from a process of dialect/standard convergence but results from an abrupt transformation of the urban setting, which took place when the former Austrian South Tyrol became a part of Italy and Bolzano was affected by massive migration movements from different areas of Italy; it was indeed the re-settlement of people speaking different varieties of Italian and/or different Italo-Romance dialects that created the conditions for the formation of Bolzano Italian. Drawing on the results of two recent sociophonetic studies, the one addressing the social distribution of affricate variants among Italian speakers, the other investigating voicing variation in bilingual speakers' social networks, Vietti provides some evidence of endogenous and exogenous contact to support the view that Bolzano Italian is to be considered as a new town koine. Moreover, some results suggest that this variety is converging toward a general northern Italian linguistic model.

Chapter 8 combines a production and perception approach to the study of restandardization. In particular, Calamai explores the relationship between standard and vernacular in Tuscany by offering a state-of-the art of both production and perception of the Tuscan vernacular. After providing an overall picture of the most relevant variables occurring at the phonetic level, the author discusses some acoustic data and presents the diffusion of some local dialectal features inside the region. In the second part of the study, Calamai discusses the perception of the Florentine pronunciation by means of a verbal-guise experiment. It is shown that the prestige of Florentine pronunciation is declining at the supra-regional level, but not inside the region. Also the data show that some sub-regional (local) features enjoy covert prestige, which is explained as a result of their diffusion inside the region. 
Chapter 9 is devoted to dialect/standard contact in southern Italy. In this chapter, Amenta examines the case of the Phrasal Verb Constructions (PVCs) in Sicilian Italian and dialect from both a synchronic and diachronic viewpoint. PVCs, which are composed by a verbal base and a locative or direction marking particle (e.g. andare via, 'go away'), represent a good example of the intertwining of internal and external factors at work in the ongoing restandardization process of Italian. These constructions exist in standard Italian and are also frequent in many regional Italian varieties and Italo-Romance dialects. Furthermore, since their use is spreading, they can be construed as a feature of neo-standard Italian. By analyzing PVCs in contemporary Sicilian Italian and in Old Sicilian (fourteenth-fifteenth centuries), Amenta aims at showing that the increasing diffusion of PVCs in regional Italian can be explained in first place by internal factors, i.e. as an effect of the linguistic contact between dialect and Italian in Sicily. However, the diachronic examination of PVCs in contemporary regional Sicilian vs. Old Sicilian also highlights differences between the two linguistic stages as far as their syntactic and semantic features are concerned. This discrepancy, which cannot be due to standard/dialect contact, is ultimately attributed by the author to the effect of the contact with other Italian varieties and, therefore, to the action of external forces.

The focus of the third part of the volume is on the effects of language contact on restandardization dynamics, in particular on the contact between Italian and languages other than substrata. In chapter 10 and 11 attention will be paid to the standardization of linguistic features borrowed from English. Chapter 12 deals with the developmental tendencies of standard Italian in Switzerland (which partly relate to the contact with German and French) as compared to those of standard Italian in Italy.

In chapter 10, Bombi focuses on exogenous neology by analyzing a number of Anglicisms in Italian from a morphological viewpoint. The author scrutinizes different language contact phenomena focusing on loanwords and calques. Bombi aims at illustrating how English has influenced contemporary Italian by promoting the creation of new morphemes and by introducing or strengthening certain word-formation rules. All the cases of lexical and morphosyntactic interference examined in this chapter have favored the spread and success of new types of word-formation rules: while these rules were initially of limited use, mostly occurring e.g. in special languages, they have subsequently become usual in everyday language. As a result of their spreading, the exogenous innovations examined in this chapter have fast become characteristic of neo-standard Italian. Evidence of this is provided by Bombi's numerous examples showing that loanwords and calques from English are well-attested in journalistic writing, which is receptive of innovations and, in turn, represents a linguistic model for further 
texts. The morphological analysis of word-formation patterns provided by Bombi is ideally complemented by the study on lexical variation presented by Asnaghi in the following chapter.

Also based on newspaper texts, chapter 11 provides a quantitative analysis of the frequency of English/Italian onomasiologically connected lexical pairs, such as break/pausa. In this chapter, Asnaghi tackles the lexical variation between the Italian word and its English onomasiological counterpart focusing on the diffusion of one lexical item with respect to the other in different regions. This approach rests on the fresh hypothesis that Anglicisms may not enter Italian in equal measure throughout the entire peninsula. In addition, the author's hypothesis is tested by means of a recently developed methodology which is here applied to Italian for the first time. The data presented in this chapter have been automatically gathered through siterestricted web searches in about 500 online newspaper websites, which are based in over 150 locations in Italy. After being collected, the data have been statistically analyzed and graphically arranged in maps containing isogloss-like drawings, which provide an easy-to-read picture of the geographical distribution of each member of the examined onomasiological pairs.

Chapter 12 deals with Italian in Switzerland, whose features are slightly different from those of Italian in Italy. In this chapter, Pandolfi provides an overview of both the vitality and the "forms of life" of Italian in Switzerland, and addresses the major features of Switzerland Italian differentiating it from Italian in Italy. These features mainly concern the lexicon, and rely partly on the centuries-old contact with the two Swiss national majority languages (German and French) and partly on the need for a Swiss institutional terminology. Moreover, Pandolfi contends that Italy and the Italian-speaking part of Switzerland represent two different "centers" of cultural elaboration and linguistic normativity, thus arguing that Italian may be considered as a pluricentric (or, rather, "bicentric") language. In particular, Italian is claimed to be a language with two asymmetric centers; the Swiss center is indeed regarded as a "rudimentary centre" (as per Ammon's 1989 terminology), in that the codes are exogenous, but the models are partly endogenous.

Finally, chapter 13 discusses the main theoretical issues concerning the notion of neostandard, and set the development of neo-standard Italian in the context of similar processes affecting other European languages. In fact, Auer states that comparable processes have led (and are still leading) to the emergence of various "neo-standards" in many European countries. As in Italy, such processes are related to the demise of traditional dialects, on the one hand, and the massive spread of the standard language, on the other hand. At the same time, Auer suggests that regional sub-standards, regional standards, and neo-standard represent three different phases, as well as three different forms, of demotization; and hence argues for keeping regional standards apart from neo-standard (while most authors in this volume consider the former as "incorporated" 
into the latter; cf. § 2). Moreover, in the light of Auer's (2005) theoretical framework, he depicts a cone-shaped diagram including a neo-standard variety, which is maintained to represent both the Italian and the German situation. Finally, neo-standard is claimed to be associated with orality, informality, subjectivity/personalization and modernity, and the consequent impact of neo-standard on traditional standard is dealt with.

This book brings together, for the first time, several studies aiming to offer a comprehensive account of neo-standard Italian. The different chapters tackle various aspects of the restandardization of Italian by analyzing empirical data from several theoretical perspectives. On the whole, however, the papers presented in this volume probably raise more questions than they give answers. Therefore, beside its primary goal of giving an overview of the restandardization dynamics at stake in Italian, this book also has another, long-term goal, which is encouraging further research. Indeed, still a lot of work needs to be done and new research is required to deepen our insights in a number of questions, such as - just to mention a few -, the position of the literary standard with respect to the neo-standard variety in the Italian linguistic repertoire; the precise relationship between neo-standard Italian and regional standards; or whether we need to distinguish between spoken Italian and written Italian when it comes to the neo-standard variety. We can only endorse Peter Auer's conclusions, which call for further research into these, and other issues.

\section{References}

Alfonzetti, Giovanna. 2002. La relativa non-standard. Italiano popolare o italiano parlato?. Palermo: Centro di Studi Filologici e Linguistici Siciliani.

Amenta, Luisa \& Marina Castiglione. 2003. Convergenza linguistica fra conoscenza, uso e percezione. L'italiano regionale in Sicilia. In Nicoletta Maraschio \& Teresa Poggi Salani (eds.), Italia linguistica anno Mille. Italia linguistica anno Duemila, 287-301. Roma: Bulzoni.

Ammon, Ulrich (ed.). 1989. Status and Function of Languages and Language Varieties. Berlin \& New York: Mouton de Gruyter.

Ammon, Ulrich. 2003. On the Social Forces that Determine what is Standard in a Language and on Conditions of Successful Implementation. Sociolinguistica 17. 1-10.

Antonelli, Giuseppe. 2011. Lingua. In Andrea Afribo \& Emanuele Zinato (eds.), Modernità italiana. Cultura, lingua e letteratura dagli anni Settanta a oggi, 15-52. Roma, Carocci.

Auer, Peter. 2005. Europe's sociolinguistic unity, or: a typology of European dialect/standard constellations. In Nicole Delbecque, Johan van der Auwera \& Dirk Geeraerts (eds.), 
Perspectives on variation. Sociolinguistic, historical, comparative, 7-42. Berlin \& New York: Mouton de Gruyter.

Auer, Peter \& Frans Hinskens. 1996. The convergence and divergence of dialects in Europe. New and not so new developments in an old area. Sociolinguistica 10. 1-30.

Auer, Peter \& Helmut Spiekermann. 2011. Demotization of the standard variety or destandardization? The changing status of German in late modernity (with special reference to south-western Germany). In Tore Kristiansen \& Nikolas Coupland (eds.), Standard Languages and Language Standards in a Changing Europe, 161-176. Oslo: Novus Press.

Berretta, Monica. 2002. Quello che voglio dire è che: le scisse da strutture topicalizzanti a connettivi testuali. In Gian Luigi Beccaria \& Carla Marello (eds.), La parola al testo. Scritti per Bice Mortara Garavelli, I, 15-31. Alessandria: dell'Orso.

Berruto, Gaetano. 1989. On the Typology of Linguistic Repertories. In Ulrich Ammon (ed.), Status and Function of Languages and Language Varieties, 552-569. Berlin \& New York: Mouton de Gruyter.

Berruto, Gaetano. 2003. Sul parlante nativo (di italiano). In Hans-Ingo Radatz \& Rainer Schlösser (eds.), Donum grammaticorum. Festschrift für Harro Stammerjohann, 1-14. Tübingen: Niemeyer.

Berruto, Gaetano. 2005. Dialect/standard convergence, mixing, and models of language contact: the case of Italy. In Peter Auer, Frans Hinskens \& Paul Kerswill (eds.), Dialect change. Convergence and divergence in European languages, 81-97. Cambridge: Cambridge University Press.

Berruto, Gaetano. 2007. Sulla vitalità sociolinguistica del dialetto, oggi. In Gianmario Raimondi \& Luisa Revelli (eds.), La dialectologie aujourd'hui, 133-153. Alessandria: dell'Orso.

Berruto, Gaetano. 2011. Italiano lingua pluricentrica?. In Anja Overbeck, Wolfgang Schweickard \& Harald Volker (eds.), Lexikon, Varietät, Philologie. Romanistische Studien. Günter Holtus zum 65. Geburtstag, 15-26. Berlin \& New York: Mouton de Gruyter.

Berruto, Gaetano. 2012 [1987]. Sociolinguistica dell'italiano contemporaneo. 2nd edn. Roma: Carocci. (1987: Roma: La Nuova Italia Scientifica).

Bombi, Raffaella. 2009. La linguistica del contatto: tipologie di anglicismi nell'italiano contemporaneo e riflessi metalinguistici. Roma: Il Calamo.

Bonomi, Ilaria. 2002. L'italiano giornalistico. Dall'inizio del '900 ai quotidiani on line. Firenze: Cesati.

Bonomi, Ilaria, Andrea Masini \& Silvia Morgana. 2003. La lingua italiana e i mass media. Roma: Carocci. 
Bruni, Francesco (ed.). 1992. L’italiano nelle regioni: lingua nazionale e identità regionali. Torino: UTET.

Canepari, Luciano. 1999. Il MaPI. Manuale di pronuncia Italiana. Bologna: Zanichelli.

Cardinaletti, Anna. 2004. L'italiano contemporaneo: cambiamento in atto e competenza dei parlanti. In Anna Cardinaletti \& Fabrizio Frasnedi (eds.), Intorno all'italiano contemporaneo. Tra linguistica e didattica, 49-75. Milano: FrancoAngeli.

Cardinaletti, Anna \& Nicola Munaro (eds.). 2009. Italiano, italiani regionali e dialetti. Milano: FrancoAngeli.

Castellani, Arrigo. 1982. Quanti erano gl'italofoni nel 1861?. Studi linguistici italiani 8. 3-26.

Celata, Chiara \& Silvia Calamai (eds.). 2014. Advances in Sociophonetics. Amsterdam \& Philadelphia: Benjamins.

Cerruti, Massimo. 2011. Regional varieties of Italian in the linguistic repertoire. International Journal of the Sociology of Language 210. 9-28.

Cerruti, Massimo. 2013. Varietà dell'italiano. In Gabriele Iannaccaro (ed.), La linguistica italiana all'alba del terzo millennio (1997-2010), 91-127. Roma: Bulzoni.

Cerruti, Massimo, Elisa Corino \& Cristina Onesti (eds.). 2011. Formale e informale. La variazione di registro nella comunicazione elettronica. Roma: Carocci.

Cerruti, Massimo \& Riccardo Regis. 2014. Standardization patterns and dialect/standard convergence: a North-Western Italian perspective. Language in Society 43(1). 83-111.

Chambers, Jack K. 2004. Dynamic typology and vernacular universals. In Bernd Kortmann (ed.), Dialectology Meets Typology: Dialect Grammar from a Cross-Linguistic Perspective, 128145. Berlin \& New York: Mouton de Gruyter.

Chini, Marina. 2011. New linguistic minorities: repertoires, language maintenance and shift. International Journal of the Sociology of Language 210. 47-69.

Cini, Monica \& Riccardo Regis (eds.). 2002. Che cosa ne pensa oggi Chiaffredo Roux? Percorsi della dialettologia percezionale all'alba del nuovo millennio. Alessandria: dell'Orso.

Cortelazzo, Manlio, Nicola De Blasi, Gianrenzo P. Clivio (eds.). 2002. I dialetti italiani. Storia, struttura e uso. Torino: UTET.

Coseriu, Eugenio. 1980. "Historische Sprache” und "Dialekt”. In Joachim Göschel, Pavle Iviæ \& Kurt Kehr (eds.), Dialekt und Dialektologie, 106-22. Wiesbaden: Steiner.

Coupland, Nikolas \& Tore Kristiansen. 2011. SLICE: Critical perspectives on language (de)standardisation. In Tore Kristiansen \& Nikolas Coupland (eds.), Standard Languages and Language Standards in a Changing Europe, 11-35. Oslo: Novus. 
Crocco, Claudia. 2015. Corpora e testi di italiano contemporaneo. In Maria Iliescu \& Eugeen Roegiest (eds.), Manuel des anthologies, corpus et textes romans, 509-534. Berlin \& New York: Mouton De Gruyter.

D’Achille, Paolo. 1990. Sintassi del parlato e tradizione scritta della lingua italiana. Analisi di testi dalle Origini al secolo XVIII. Roma: Bonacci.

Dal Negro, Silvia \& Alessandro Vietti. 2011. Italian and Italo-Romance dialects. International Journal of the Sociology of Language 210. 71-92.

Dardano, Maurizio, Gianluca Frenguelli \& Teresa Perna. 2000. L'italiano di fronte all'inglese alle soglie del terzo millennio. In Serge Vanvolsem, Dieter Vermandere, Franco Musarra \& Bart Van Den Bossce (eds.), L'italiano oltre frontiera, I, 31-55. Leuven/Firenze: Leuven University Press/Franco Cesati.

De Mauro Tullio. 1976 [1963]. Storia linguistica dell'Italia unita. 2nd edn. Roma \& Bari: Laterza.

De Mauro, Tullio (ed.). 1994. Come parlano gli italiani. Firenze: La Nuova Italia.

Durante, Marcello. 1985. Dal latino all'italiano moderno. Bologna: Zanichelli.

Ferguson, Charles A. 1959. Diglossia. Word 15. 325-340.

Galli de' Paratesi, Nora. 1984. Lingua toscana in bocca ambrosiana. Tendenze verso l'italiano standard: un'inchiesta sociolinguistica. Bologna: Il Mulino.

Geeraerts, Dirk \& Dirk Speelman. 2014. A lectometric definition of demotisation and destandardisation. Paper presented at the International Conference Taal \& Tongval, Ghent University, 28 November.

Gili Fivela, Barbara, Cinzia Avesani, Marco Barone, Giuliano Bocci, Claudia Crocco, Mariapaola D’Imperio, Rosa Giordano, Giovanna Marotta, Michelina Savino \& Patrizia Sorianello. 2015. Intonational phonology of the regional varieties of Italian. In Sónia Frota \& Pilar Prieto (eds.), Intonation in Romance. Oxford: Oxford University Press.

Grassi, Corrado, Alberto A. Sobrero \& Tullio Telmon. 1997. Fondamenti di dialettologia italiana. Roma \& Bari: Laterza.

Grasso, Daniele Emanuele. 2007. Innovazioni sintattiche in italiano (alla luce della nozione di calco). Université de Genève: Ph.D. dissertation.

Guerini, Federica \& Silvia Dal Negro (eds.). 2011. Italian sociolinguistics: twenty years on. [Special Issue]. International Journal of the Sociology of Language 210.

Hajek, John. 2012. (Non-)dominant varieties of a (non-) pluricentric language? Italian in Italy and Switzerland. In Rudolph Muhr (ed.), Non-Dominant Varieties of Pluricentric Languages: Getting the Picture. In memory of Michael Clyne. Frankfurt am Main: Peter Lang. 
Holtus, Günther \& Edgar Radtke (eds.). 1985. Gesprochenes Italienisch in Geschichte und Gegenwart. Tübingen: Narr.

Iacobini, Claudio \& Francesca Masini. 2009. I verbi sintagmatici dell'italiano fra innovazione e persistenza: il ruolo dei dialetti. In Anna Cardinaletti \& Nicola Munaro (eds.), Italiano, italiani regionali e dialetti, 115-135. Milano: FrancoAngeli.

Iannàccaro, Gabriele \& Vittorio Dell'Aquila. 2011. Historical linguistic minorities: suggestions for classification and typology. International Journal of the Sociology of Language 210. $29-45$.

Kloss, Heinz. 1978. Die Entwicklung neuer germanischer Kultursprachen seit 1800. Düsseldorf: Schwann.

Koch, Peter \& Wulf Österreicher. 1985. Sprache der Nähe-Sprache der Distanz. Mündlichkeit und Schriftlichkeit im Spannungsfeld von Sprachtheorie und Sprachgeschichte. Romanistisches Jahrbuch 36. 15-43.

Kristiansen, Tore, Peter Garrett \& Nikolas Coupland. 2005. Introducing subjectivities in language variation and change. Acta Linguistica Hafniensia 37(1). 9-35.

Kristiansen, Tore \& Jens Jørgensen. 2005. Subjective factors in dialect convergence and divergence. In Peter Auer, Frans Hinskens \& Paul Kerswill (eds.), Dialect change. Convergence and divergence in European languages, 287-302. Cambridge: Cambridge University Press.

Kristiansen, Tore \& Nikolas Coupland (eds.). 2011. Standard Lanaguages and Language Standards in a Changing Europe. Oslo: Novus.

Kristiansen, Tore \& Stefan Grondelaers (eds.). 2013. Language (de)standardisation in Late Modern Europe: Experimental Studies. Oslo: Novus.

Lepschy, Giulio. 2002. Mother Tongues and Other Reflections on the Italian Language. Toronto: University of Toronto Press.

Maiden, Martin and Mair M. Parry (eds.). 1997. The dialects of Italy. London: Routledge.

Maiden, Martin, John C. Smith and Adam Ledgeway. 2011-2013. The Cambridge history of the Romance languages. Cambridge: Cambridge University Press.

Marzo, Stefania \& Claudia Crocco. 2015. Sulla tipicità delle costruzioni presentative per l'italiano neostandard. Revue Romane 50(1). 30-50.

Mattheier, Klaus J. 1996. Varietätenkonvergenz. Überlegungen zu einem Baustein einer Theorie der Sprachvariation. Sociolinguistica 10. 31-52.

Mattheier, Klaus J. 1997. Über Destandardisierung, Umstandardisierung und Standardisierung in modernen europaïschen Standardsprachen. In Klaus J. Mattheier \& Edgar Radtke (eds.), 
Standardisierung und Destandardisierung europaïscher Nationalsprachen, 1-9. Frankfurt am Main: Peter Lang.

Mioni, Alberto M. 1983. Italiano tendenziale: osservazioni su alcuni aspetti della standardizzazione. In Paola Benincà, Manlio Cortelazzo, Aldo Prosdocimi, Laura Vanelli \& Alberto Zamboni (eds.), Scritti linguistici in onore di Giovan Battista Pellegrini, 495-517. Pisa: Pacini.

Moretti, Bruno. 2006. Nuovi aspetti della relazione italiano-dialetto in Ticino. In Alberto A. Sobrero \& Anna Miglietta (eds.), Lingua e dialetto nell'Italia del duemila. Galatina: Congedo. $31-48$.

Parry, Mair. 2010. Sociolinguistics in Italy. In Martin J Ball (ed.), Routledge handbook of sociolinguistics around the world. 327-240, London \& New York: Routledge.

Rohlfs, Gerhard. 1966. Grammatica storica della lingua italiana e dei suoi dialetti. Torino: Einaudi.

Ruffino, Giovanni (ed.). 1995. Percorsi di Geografia linguistica. Palermo: Centro di studi filologici e linguistici siciliani.

Sabatini, Francesco. 1985. L'“italiano dell'uso medio": una realtà tra le varietà linguistiche italiane. In Günther Holtus \& Edgar Radtke (eds.), Gesprochenes Italienisch in Geschichte und Gegenwart. 154-184. Tübingen: Narr.

Scivoletto, Giulio. 2014. L'italianizzazione dei dialetti come caso di convergenza linguistica. Rivista Italiana di Dialettologia 38. 75-101.

Serianni, Luca \& Pietro Trifone (eds.). 1993. Storia della lingua italiana. Vol.1 ${ }^{\circ}$ I luoghi della codificazione. Torino: Einaudi.

Sobrero, Alberto A. \& Annarita Miglietta (eds.). 2006. Lingua e dialetto nell'Italia del duemila, Galatina: Congedo.

Sornicola, Rosanna. 1981. Sul parlato. Bologna: Il Mulino.

Telmon, Tullio. 1993. Varietà regionali. In Alberto A. Sobrero (ed.), Introduzione all'italiano contemporaneo, II, 93-149. Roma \& Bari: Laterza.

Trifone, Pietro. 1992. Roma e il Lazio. In Francesco Bruni (ed.), L’italiano e le regioni. Lingua nazionale e identità regionali, 540-593. Torino: UTET.

Trudgill, Peter. 2011. Sociolinguistic Typology. Social Determinants of Linguistic Complexities. Oxford: Oxford University Press.

UNESCO 2003 = UNESCO Ad Hoc Expert Group on Endangered Languages, Language vitality and endangerment. Document submitted to the International Expert Meeting on UNESCO Programme Safeguarding of Endangered Languages (Paris, 10-12 March 2003), http://www.unesco.org/culture/ich/doc/src/00120-EN.pdf(accessed 10 May 2016). 
Vincent, Nigel. 2006. Languages in contact in Medieval Italy. In: Anna Laura Lepschy \& Arturo Tosi (eds.), Rethinking languages in contact: the case of Italian, 12-27. London: Legend. Voghera, Miriam. 1992. Sintassi e intonazione dell'italiano parlato. Bologna: Il Mulino.

Volkart-Rey, Ramón. 1990. Atteggiamenti linguistici e stratificazione sociale. La percezione dello status sociale attraverso la pronuncia. Roma: Bonacci. 